\title{
Effect of Remuneration on Employee Job Satisfaction at the Public Service Commission in Kenya
}

\author{
Nyaga, Juliet Wambeti \\ School of Business, Laikipia University, P.O. Box 1100-20300 Nyahururu, Kenya \\ Gakobo, Thomas Waweru \\ School of Business, Laikipia University, P.O. Box 1100-20300 Nyahururu, Kenya \\ Njuguna, Peter Mwaura \\ School of Business, Laikipia University, P.O. Box 1100-20300 Nyahururu, Kenya
}

\begin{abstract}
Over the years, job satisfaction is considered to be one such factor that has attracted the attention of not only government agencies, organizations, businesses, banks, and independent institutions but it has also proven to be an important aspect in academic institutions. In light of the above scenario the Kenya public service is not an exception. Although the mandate of the commission is to provide competent human resource in the public service, low morale and lack of staff motivation has remained a major challenge that Public Service Commission has to endure over the years. The objective of the study was to evaluate the effect of remuneration on job satisfaction at the Public Service Commission in Kenya. The study adopted a descriptive research design. The population for this study was 200 Public Service Commission employees. A stratified random sampling technique was employed to select a sample of 132 respondents. A five likert scale questionnaire was used to collect data which was analyzed through descriptive and inferential statistical analysis. The study found out that that Remuneration has a statistical significantly effect on employee job satisfaction at the Public Service Commission in Kenya at 95\% confidence level. The study concluded that remuneration is an important factor affecting employee job satisfaction at the Public Service Commission in Kenya. The study recommended that the Public Service Commission in Kenya should improve on financial and non-financial compensation and increase employee wages in order to boost employee e satisfaction and enhance performance of public servants.
\end{abstract}

Key Words: Remuneration, Job Satisfaction, Public Service Commission

DOI: $10.7176 / \mathrm{DCS} / 10-10-07$

Publication date:October $31^{\text {st }} 2020$

\section{Introduction}

Job satisfaction describes how content an individual is with his or her job. It is a relatively recent term since in previous centuries the jobs available to a particular person were often predetermined by the occupation of that person's parent. Job satisfaction is a very important attribute which is frequently measured by organizations (Woodruffe, 2000). The most common way of measurement is the use of rating scales where employees report their reactions to their jobs. People management is an important aspect of organizational processes. This emanated from the recognition that the human resources of an organization and the organization itself are synonymous. A well-managed business organization normally considers the average employees as the primary source of productivity gains. These organizations consider employees rather than capital as the core foundation of the business and contributors to firm development. To ensure the achievement of firm goals, the organization creates an atmosphere of commitment and cooperation for its employees through policies that facilitate employee satisfaction. Satisfaction of human resource finds close links to highly motivated employees. The earliest strategy is to use wage increases to link job satisfaction and motivation to organizational commitment (Hill \& Wiens-Tuers 2002). With the recognition that this is not enough to bring about motivation expressed in job satisfaction, other perspectives emerged giving particular importance to the training and skills development of employees (Woodruffe 2000) applied through the underlying principle of continuous organizational learning. Since this covers only an aspect of human resource management, a holistic approach emerged that targets the development of a certain quality of employment life (Champion-Hughes 2001).

Job satisfaction at work can take place in two ways. One, people can motivate themselves by seeking, finding and carrying out (or being given) work that satisfies needs (intrinsic motivation) and two people can be motivated by management through such methods as pay, promotion, praise (extrinsic motivation). Intrinsic job satisfaction determinants can be said to be self-generated factors that influence employees to be satisfied with their job. Extrinsic job satisfaction factors refer to what is done to or for people to satisfy them at the work place (Gathungu \& Wachira, 2013). This means that achieving motivation and job satisfaction to develop organizational 
commitment is not simple or easy and works according to the context of individual firms. Although, there are best practices within industries, it is up to the individual organizations to determine which human resource strategies meet its needs and objectives. To determine the manner that individual industries develop and achieve organizational commitment through job satisfaction and motivation, the study investigated factors influencing employee job satisfaction with a specific focus on the Public Service Commission.

The Commission dates back to 1954 when Civil Service Commission was established by British Colonial Government following Holmes Commission Report, 1948. At formation, the commission played an advisory role to the Governor in matters of appointments. At independence in 1963 it was enshrined in the constitution and renamed Public Service Commission after which its mandate has expanded over years especially under the Constitution of Kenya 2010. The Commission, since then, has handled matters of human resource management in the public service especially the civil service and local authorities. Article 234 of the Constitution outlines the functions and powers of the Public Service Commission. According to the article the Commission is expected to, among other things; establish and abolish office in the public service; appoint persons to hold or act in public offices, and to confirm appointments; and exercise disciplinary control over and remove persons holding or acting in those offices

\section{Statement of the Problem}

Research has shown that satisfied employees are more productive, deliver higher quality work and improve organization's competitiveness and success. Additionally, job satisfaction continues to play an important role, as the landscape of work across the world has been changing dramatically over the past 15-20 years in response to economic shifts, technological advances, and an increasingly global economy. Due to these dynamism and unpredictability of the workforce scenery, most organizations have been faced with the challenging task of motivating their employees through provision of attractive working conditions and competitive remuneration. Despite the fact that Public service reforms in Kenya span the last five decades since independence, these reforms have been characterized by some remarkable successes, challenges and lessons learnt. The mandate of the commission is to transform the public service to become professional, efficient and effective for the realization of national development goals and to be the lead service commission in the provision, management and development of competent human resource in the public service. However, studies on Kenya Public Service have consistently pointed at low morale and motivation as some of the enduring challenges that the service faces. It is in this background that this study sought to evaluate the effect of remuneration on employee job satisfaction at Public Service Commission, Kenya

\section{Literature Review}

A study by Joanna (2015) on the relation between remuneration and job satisfaction, a case study of public administration employees in pomerania region in Poland. The aim of this paper was determining how remuneration affects job satisfaction among public administration employees from one of Eastern-European countries. The study was conducted by carrying out a survey among employees of 10 public administration offices of the Pomerania Region in Poland. The study findings showed that highly remunerated employee had a high level of job satisfaction that employee with lower remuneration packages. The analysis of the results allowed drawing conclusions that remuneration has significance on overall job satisfaction. However the study scope was in European organizations and thus findings may not accurately relate with how remunerations affects employee job satisfaction in Kenya public service.

Similary, Robbins (2011), in the study on the effect of employees' remuneration on job satisfaction in Canada. The study main objective was to determine how different remuneration packages affect employee job satisfaction in Canadian public institutions. The study applied a descriptive cross sectional survey design and sampled a total of 3000 respondents. The study findings indicated that remuneration packages likes salary or wages containing benefits or rewards such as accommodation, a car, telephone, gas or electricity allowances, meals or milk improved the level of job satisfaction. The study recommended that working out a good remuneration package help to attract, retain and encourage the right employees and improved the level of job satisfaction. However the study failed to show how financial and non-financial compensation and wage increase affects job satisfaction in organizations.

In addition, in a study by Hiqma (2016) on the Effect of Remuneration, Job Satisfaction and OCB on the Employee Performance in East Java, Indonesia. The study aims was to analyze the effect of remuneration, job satisfaction and Organizational Citizenship Behavior (OCB) on employee performance; analyze the job satisfaction as a mediating variable of the effect remuneration on employee performance; and analyze OCB role in mediating the 
effect of remuneration and job satisfaction on employee performance. Data was collected using saturated sampling method. The population consisted of 138 Account Representative (AR) Supervision of the work in the Tax Office in Malang area, the Regional Office of Directorate General of Taxes East Java III. The study findings showed that remuneration and satisfaction positively and significantly effect AR satisfaction and OCB respectively, but remuneration does not significantly effect OCB. The results of this study indicate that the concept of the higher the remuneration received by employees, the higher their performance will be, only occurs in normal conditions. If there are obstacles in the work implementation process, then this concept does not apply. Therefore, the Directorate General of Taxation institution must provide the solution and attention to the barriers experienced by AR Supervision in order to maximize their performance.

Additionally, a study by Schermerhorn (2012) on the effect of remuneration on employee job satisfaction in Nigeria Oil firms recommended that employee wages should be reviewed upward on annual. However, the study was undertaken in Oil companies and therefore the findings may not portray the effect of remuneration on employee job satisfaction in Kenya public service. Okalo (2012) did a study on factors affecting employees job satisfaction in Kenya public institutions. The study employed a descriptive design and sample population was obtained from public institutions. However, the study failed to show how employee remuneration affected employee job satisfaction in terms of financial and non-financial compensation and wage increase. Curral (2012) undertook a study on factors affecting employee job satisfaction in USA government organizations, the study findings indicated that employee remuneration and rewards were the major factors affecting employee job satisfaction. However, the study was undertaken in different organizations in a developed country and thus the findings may not be applied to examine the effect of remuneration on job satisfaction in Public Service Commission in Kenya. On the other hand, Mitchell (2015) undertook a study on effect of employee remuneration on employee job satisfaction in UK firms and found out that remuneration was not the only factor that affected employee job satisfaction since other factors like working conditions affected job satisfaction. The study however also failed to examine the effect of remuneration on job satisfaction within the local context and hence the findings are short in explaining the effect of remuneration on employee job satisfaction in local organizations like Public Service Commission in Kenya. This study will attempt to identify other compensation factors that affect employee remuneration and affect job satisfaction in Public Service Commission in Kenya.

Contrary, a study by Magalla (2011) established that employee remuneration was major factor leading to low level of employee job satisfaction in many public organizations in Kenya. The study however did not specifically explain how employee remuneration in terms of financial and nonfinancial compensation and wages increase affected employee job satisfaction in Public Service Commission in Kenya. This study will fill the missing knowledge gap by examining the effect of remuneration on job satisfaction in Public Service Commission in Kenya. Similary, findigs from as study by Zobla (2008) on employee remuneration in Ghana identified that remuneration is an important factor contributing to employee job satisfaction for retention and for turnover since it acts as a major motivation for employees who want to stay committed to the organization in turn enhancing the attraction as well as the retention (Zobla, 2008). When an employee is paid well for the services offered to the employer, it shows the employee that their existence in the organization matters (Rogelberg, S. G., Allen, J. A., Shanock, L., Scott, C. W., \& Shuffler, M., 2010). Employees are more satisfied when they feel they are being paid fairly for the work they do. According to Sweeney, A., Hohenshil, T. \& Fortune, J. (2002), the importance of money in employee job satisfaction should not be underestimated since everybody needs money and all employees work so that they can earn money. The main purpose behind all of this is nothing but money. So, compensation plays an important role in the job satisfaction of the employees. For them, the service quality, organizational performance and job satisfaction can all be increased if the employees are given good salaries, which are a great motivator as well as employee job satisfaction. Results of survey by Kathawala, Moore \& Elmuti (2002) found that salary was ranked to be the prime factor for the motivation and job satisfaction of salaried employees of an automobile industry. The survey tried to assess the various job characteristics and the way the employees ranked them as motivators and satisfiers. The results showed that compensation was ranked as the number one job element for job satisfaction and increase in salary for performance was ranked as the number one job element for motivation.

Akintoye (2001) asserts that money remains the most significant motivational strategy. As far back as 1911, Fredrick Taylor and his scientific management associate described money as the most important factor in motivating the industrial workers to achieve greater productivity. Taylor advocated the establishment of incentive wage systems as a mean of stimulating workers to higher performance, commitment, and success. Katz, in Holland, P., Pyman, A., Cooper, B. K., Sinclair P. \& Teicher, J. (2011) demonstrates the motivational power of money through the process of job choice, he further explains that money has the power to attract, retain, and motivate individuals towards higher performance. Holland et al. (2011), confirm that the earliest strategy is to use wage increases to link job satisfaction and motivation to organizational commitment. Since this covers only an aspect 
of human resource management, a holistic approach emerged that targets the development of a certain quality of employment life that covers fair wages, benefits, other employment conditions and career development to support the facilitation of motivation and job satisfaction directed towards organizational commitment. By and large, compensation is a very valuable tool for retention and turnover. It also works as communicator when it is given to employee against his or her services which shows how much an employee is valuable for the organization (Zobal, 2008). Probably the most influential factor in job satisfaction is the remuneration one gets for his/her job: a reasonable pay which will compensate for many hitches, for example work overload, overtime or even a stressful job (Sweeney et al., 2002). Job satisfaction is directly related to remuneration packages and dissatisfaction mostly comes up when a worker feels that he or she is not being appropriately compensated for the work s/he is doing for the company.

\section{Methodology}

The study employed a descriptive survey research design. This design was considered appropriate because the study had clearly stated variables and aimed at drawing inferences about possible relationships among the variables of the study (Cooper and Schindler, 2003). The study targeted 200 employees in the Public Service Commission of Kenya. The sample size was calculated using the Vause (2002) sample calculation formula leading to a sample of 132 respondents. According to Vause (2002), the sample size should be determined on the basis of those variables in the sample that are likely to have greatest variability and if the likely proportion is not known, it can be assumed that $50 \%$ of the sample. Stratified random sampling technique was employed to pick the respondents who participated in the study. A semi-structured questionnaire was developed tested and administered to respondents using the drop and pick method. The collected data was analyzed using descriptive and inferential statistics aided by Statistical Package for Social Sciences (SPSS version 23). Descriptive statistics data analysis method was applied where data was computed using measures of central tendency such as frequencies, percentages, standard deviation and variance results. In addition, the researcher employed thematic analysis to analyze all the qualitative data collected from respondents. This is because qualitative data cannot be subjected to statistical analysis. Inferential statistics was used to analyze quantitative data through the use of Linear Regression model to establish the significance relationship of the independent variables on the dependent variable. Analysis of Variance (ANOVA) was applied to test the significance of the overall regression model which determined the significant relationship between the research variables and applied to test research hypotheses.

\section{Results and Discussion}

The study sought to examine the effect of remuneration on job satisfaction in Public Service Commission in Kenya. The study requested respondents to indicate their level of agreement with key statements in relation to the effect of remuneration on job satisfaction in Public Service Commission in Kenya using a scale of 1-5 (1-Strongly Disagree, 2-Disagree, 3-Moderately agree, 4-Agree 5-Strongly agree). The findings are presented in Table 4.3. According to study findings in Table 1 below, the respondents disagreed that staff receive salaries that commensurate to the duties they perform as indicated by a mean of 1.9318 and a standard deviation of 1.03521; the respondents then agreed that they are provided with other benefits that come in addition to the salary as indicated by a mean of 4.3333 and a standard deviation of 0.61367 . The respondents agreed that staff are paid in time as indicated by a mean of 4.0606 and a standard deviation of 1.06833 ; the respondents further disagreed that there is allowance for overtime as indicated by a mean of 1.9091 and a standard deviation of 1.06617. The respondents agreed that there is provision for personal development loans at subsidized interest rates as indicated by a mean of 4.3030 and a standard deviation of 0.83748 . Finally, the respondents disagreed that they are satisfied with my current remuneration package as indicated by a mean of 2.0303 and a standard deviation of 1.06247 . 
Table 1: Remuneration Descriptive Results

\begin{tabular}{|c|c|c|c|c|c|c|c|}
\hline \multicolumn{2}{|c|}{$\begin{array}{l}\text { Remuneration } \\
\text { Statements }\end{array}$} & \multirow{2}{*}{$\begin{array}{l}\mathbf{N} \\
132\end{array}$} & \multirow{2}{*}{$\begin{array}{r}\text { Minimum } \\
1.00\end{array}$} & \multirow{2}{*}{$\begin{array}{r}\text { Maximum } \\
5.00\end{array}$} & \multirow{2}{*}{$\begin{array}{l}\text { Mean } \\
1.9318\end{array}$} & \multirow{2}{*}{$\begin{array}{c}\begin{array}{c}\text { Std. } \\
\text { Deviation }\end{array} \\
1.03521\end{array}$} & \multirow{2}{*}{$\begin{array}{r}\text { Variance } \\
1.072\end{array}$} \\
\hline 1) & $\begin{array}{l}\text { Staff salaries } \\
\text { commensurate } \\
\text { duties }\end{array}$ & & & & & & \\
\hline 2) & $\begin{array}{l}\text { Provided with } \\
\text { benefits }\end{array}$ & 132 & 3.00 & 5.00 & 4.3333 & .61367 & .377 \\
\hline 3) & $\begin{array}{l}\text { Staff are paid in } \\
\text { time }\end{array}$ & 132 & 1.00 & 5.00 & 4.0606 & 1.06833 & 1.141 \\
\hline 4) & $\begin{array}{l}\text { Allowance for } \\
\text { overtime }\end{array}$ & 132 & 1.00 & 5.00 & 1.9091 & 1.06617 & 1.137 \\
\hline 5) & $\begin{array}{l}\text { Provision for } \\
\text { personal } \\
\text { development } \\
\text { loans }\end{array}$ & 132 & 1.00 & 5.00 & 4.3030 & .83748 & .701 \\
\hline 6) & $\begin{array}{l}\text { Satisfied with } \\
\text { remuneration } \\
\text { package }\end{array}$ & 132 & 1.00 & 5.00 & 2.0303 & 1.06247 & 1.129 \\
\hline & lid N (listwise) & 132 & & & & & \\
\hline
\end{tabular}

These findings indicates that majority of the respondents agreed that staff are provided with other benefits that come in addition to the salary, staff are paid in time and there is provision for personal development loans at subsidized interest rates. However, majority of the respondents also disagreed that staff receive salaries that commensurate to the duties they perform, there is allowance for overtime and staff are satisfied with current remuneration package. These findings shows that only few respondents had varied or divided opinions and most of the respondents gave similar responses on all the statements in relation to the effect of remuneration on job satisfaction in Public Service Commission in Kenya .Standard deviation and variance are both measures of variation for interval-ratio variables and both describe how much variation or diversity there is in a distribution (Sekeran, 2012). Standard deviation provides an indication of how far the individual responses to a question vary or deviate from the mean. It tells the researcher how spread-out the responses are from the mean, and explains if the respondents' responses are concentrated around the mean, or scattered far \& wide (Graham, 2012). If the standard deviation and variance are each greater than 1 it means that the respondents had divergent views and if they are each less than 1, then this means that the respondents had similar opinions on the issues concerned (Ramsey, 2013). These findings thus indicates that provision of employee benefits (Mean 4.3333), payment of salaries in time (Mean 4.0606), and provision for personal development loans at subsidized interest rate s(Mean 4.3030) increased the level of employee job satisfaction in Public Service Commission in Kenya (Mean 1.9318) .

However, payment of salaries that did not commensurate to the duties employees performed (Mean 1.9318), lack of allowance for overtime and lack of satisfaction amongst most staff with current remuneration package lowered the level of employee job satisfaction in the organization (Mean, 1.9091). The findings clearly demonstrate that financial and non-financial compensation and wage increase plays a significant role towards determination of how remuneration affects the level of employee job satisfaction in Public Service Commission in Kenya. These findings concurs with Curral (2012) where he indicated that employee remuneration in terms of payment of the right salaries in relation to duties performed, provision of benefits, payment of allowances and provision of personal development loans determines the level of employee job satisfaction in organizations. These findings are in agreement by Magalla (2011) where he established that employee remuneration in terms of employee benefits, payment of salaries in time and provision for personal development loans are major factors affecting the level of employee job satisfaction in many public organizations in Kenya. These findings are also in line with Muga (2014) where he identified that lack of increased level of employee job satisfaction in many public corporation can be attributed to lack of payment of salaries that full compensate the performed employee duties, lack of allowance for overtime and lack of satisfaction amongst most staff with current remuneration package. The study therefore inferred that remuneration in terms of financial and non-financial compensation and wage increase affect employee job satisfaction in Public Service Commission in Kenya. 
The regression model on employee remuneration versus employee job satisfaction was presented in Table 2 below . The coefficient of determination ( $\mathrm{R}$ square) was found to be 0.266 and $\mathrm{R}$ is 0.545 . The $\mathrm{R}$ square statistic indicates that $26.76 \%$ of of employee job satisfaction at the public service commission in Kenya is explained by the variation in employee remuneration. The $\mathrm{R}$ square statistic is observed to be quite low which implies that the model may not have a good statistical fit. This can be corrected by adding more variables onto the model. However, the Adjusted R square was found to be .0 .275 which is higher than the R square.

Table 2: Model Summary for Employee Remuneration

\begin{tabular}{llll}
\hline $\mathrm{R}$ & R Square & Adjusted R Square & Std. Error of the Estimate \\
\hline $.545^{\mathrm{a}}$ & 0.26678 & 0.27547 & 1.16921 \\
\hline
\end{tabular}

The ANOVA results presented in Table 3 below indicates that the model was significant at 95\% confidence level since the calculated $\mathrm{p}$ value was 0.001 which was less than 0.05 (95\% confidence level). This implies that the model had a good fit.

Table 3: ANOVA for Employee Remuneration

\begin{tabular}{llllll}
\hline & Sum of Squares & df & Mean Square & F & Sig. \\
\hline Regression & 19.0388 & 1 & 19.0388 & 13.9268 & $.001^{\text {b }}$ \\
Residual & 45.1129 & 33 & 1.36706 & & \\
Total & 64.1517 & 34 & & & \\
\hline
\end{tabular}

Table 4 below indicates that the that the coefficient of employee remuneration as 0.9385 which means that a unit change in employee renumeration leads to 0.9385 change in employee job satisfaction at the Public Service Commission in Kenya. The $t$ statics is for this coefficient is 3.731 with a p-value of 0.0007 which is less than 0.05 confidence interval. We therefore reject that null hypothesis that "Employee remuneration has not statistical significant effect on employee job satisfaction at the Public service commission in Kenya" and hence conclude that employee remuneration has a statistically significance effect on employee job satisfaction at the Public Service Commission in Kenya.

Table 4. Coefficients, Employee Remuneration

\begin{tabular}{lllll}
\hline & $\mathrm{B}$ & Std. Error & $\mathrm{T}$ & Sig. \\
\hline (Constant) & 0.6649 & 1.24062 & 0.5359 & 0.59562 \\
$\begin{array}{l}\text { Employee } \\
\text { Remuneration }\end{array}$ & 0.9385 & 0.2515 & 3.73187 & 0.00072 \\
\hline
\end{tabular}

Remuneration: $Y=\beta_{0}+\beta_{1} X_{1}+e$

$\mathrm{Y}=0.6649+9385 \mathrm{X}_{1}+\mathrm{e}$

\section{Conclusion}

The study sought to examine the effect of remuneration on job satisfaction in Public Service Commission in Kenya. The study found out that remuneration was major factor that affected employee job satisfaction in the organization. The findings showed that remuneration in terms of financial and non-financial compensation and wage increase affected employee job satisfaction in Public Service Commission in Kenya. The study noted that majority of the respondents agreed that staff were provided with other benefits that come in addition to the salary, staff were paid in time and there was provision for personal development loans at subsidized interest rates. However, majority of the respondents also disagreed that staff received salaries that commensurate to the duties they performed, there was allowance for overtime and staff were satisfied with current remuneration package. These findings thus indicated that provision of employee benefits, payment of salaries in time and provision for personal development loans at subsidized interest rates increased the level of employee job satisfaction in Public Service Commission in Kenya. However, payment of salaries that did not commensurate to the duties employees performed, lack of allowance for overtime and lack of satisfaction amongst most staff with current remuneration package lowered the 
level of employee job satisfaction in the organization. The findings clearly demonstrated that financial and nonfinancial compensation and wage increase plays a significant role towards determination of how remuneration affects the level of employee job satisfaction in Public Service Commission in Kenya. The study therefore inferred that remuneration in terms of financial and non-financial compensation and wage increase affect employee job satisfaction in Public Service Commission in Kenya. The study concluded that at Public Service Commission, remunerations play a major role in determining the level of employee job satisfaction. Financial and non-financial compensation and wage Increase are the major remuneration indicators which determine how employee remuneration affects job satisfaction in an organization. The study also concluded that provision of employee benefits, payment of salaries in time and provision for personal development loans at subsidized interest rates increased the level of employee job satisfaction in Public Service Commission in Kenya.

\section{Recommendation}

The Public Service Commission in Kenya should improve on financial and non-financial compensation and crease employee wages. The Public Service Commission in Kenya should provide all employees with benefits such as company car, medical plan, and pension plans. Employee should be paid salaries in time and be provided with development loans at subsidized interest rates. Employee salaries should commensurate to the duties employees performs and there should be allowances for overtime

\section{References}

Akintoye,R. (2001). Employee's Recognition and Job satisfaction. Journal of Administrative Sciences, (15). 122-144.

Cooper, R.D, \& Schindler, P. (2003). Business Research Methods. (1st Edition). New York: Age International Publishers.

Curral,P. (2012). Employees Job satisfaction and Employees Productivity. Human Resource Journal: 22 (5) 112-221.

Graham, L.K. (2012). Introduction to Survey Research Design. SRL Fall 2002 Seminar Series.

Holland, P., Pyman, A., Cooper, B. K., Sinclair P. \& Teicher, J. (2011). Employee Voice and Job Satisfaction in Australia: The Centrality of Direct Choice. Human Resource Management, 50 (1), 95-111.

Kathawala, P., Moore,E. \& Elmuti,M. (2002). Factors Affecting Employees’ Job Satisfaction. Human Resource journal, 12 (44),13-23.

Katz,M., Holland, P., Pyman, A., Cooper, B. K., Sinclair P. \& Teicher, J. (2011). Employee Voice and Job Satisfaction in Australia: The Centrality of Direct Choice. Human Resource Management, 50 (1), 95-111.

Magalla,W. (2011). Factors affecting employees job satisfaction. International journal of human resource: $6(5), 113-118$.

Muga, R. (2014). HRM practices and organizational commitment: Test of a mediation model. Canadian Journal of Administrative Sciences, 17, (2), 319-331.

Rogelberg, S. G., Allen, J. A., Shanock, L., Scott, C. W., \& Shuffler, M. (2010). Employee Satisfaction with meetings: A contemporary Facet of Job satisfaction, Human Resource Management, 49 (2), 149-172.

Sekeran, P. (2012). Research Design and Methodology. (2 ${ }^{\text {nd }}$ Edition),New Jersey,USA: Pearson Publishers.

Sweeney, A., Hohenshil, T. \& Fortune, J. (2002). "Job Satisfaction among Employee Assistance Professionals", Journal of Employment Counseling, 3,(2), 52-60.

Vause, W. (2002). Business Research Methods. Texas, USA: Harcourt College Publisher

Zobal,P. (2008). Effect of employee compensation in Asian countries on job satisfaction. Journal of Human Resource Management, 12(5). 17-122. 